\title{
Re-evaluating the changing geographies of climate activism and the state in the post-climate emergency era in the build-up to COP26
}

\author{
Andrew P. Kythreotis, Candice Howarth, Theresa G. Mercer, \\ Hannah Awcock and Andrew E. G. Jonas
}

\begin{abstract}
A key aim of much climate activism is to enhance climate ambition and hold local and national governments, as well as global governance forums like the United Nations (UN), to account for the ways in which they implement and monitor climate policy across society to reverse long-term climate change. In recent years new local forms of climate activism, particularly at the urban scale, have taken a more prominent role in this. Although place-based, such local forms of climate activism are at the same time multi-scalar in orientation and strategic focus. This is particularly true in the UK where climate activism has prompted a number of local councils to declare climate emergencies, providing a mechanism by which they can become locally accountable in the delivery of their climate action plans, whilst at the same time holding national government to prior and future commitments to global climate governance. Using interview data with experts working on climate emergency declarations research across the UK, we critically discuss four key themes that have underpinned and catalysed the changing geographies of civil-state relationships within the climate emergency and what this may mean for future global climate governance under the UNFCCC Conferences of the Parties (COP). We argue that decision-makers at COP26 need to take greater heed of the significance of this new broader urban climate activism and its role in geopolitically mobilising more equitable, democratic and inclusive forms of climate governance which give citizens and civil society more credence within global climate policy decision-making processes that have been up to now, dominated by national state discourses.
\end{abstract}

Keywords: Climate activism, climate policy and the state, climate emergency, COP26, democracy, civil society.

Notes on the authors: see end of article.

(C) The author(s) 2021. This is an open access article licensed under a

Creative Commons Attribution-NonCommercial-NoDerivs 4.0 Unported License 


\section{Introduction}

The twenty sixth United Nations (UN) Conference of the Parties (hereafter 'COP26') due to be held in November 2021 in Glasgow, UK (in partnership with Italy) aims to 'bring parties together to accelerate action towards the goals of the Paris Agreement and the UN Framework Convention on Climate Change' (UK Government \& United Nations 2020). This suggests a greater policy emphasis than in previous years to bring state and civil actors closer together in collaboration to tackle the current climate crisis and reach the goals of the Paris Agreement. This state-civil relationship is further cemented by statements that 'the UK is committed to working with all countries and joining forces with civil society [emphasis added], companies and people on the frontline of climate change to inspire climate action ahead of COP26' (UK Government \& United Nations 2020). These words resonate with what we have seen in the last few years: climate activism has come to the fore and garnered public attention globally with mass civil demonstrations happening all around the world.

Climate activism can be understood as a civil movement with the key aim of mobilising knowledge about the dangers and impacts of anthropogenic climate change (ACC) and catalysing action. Whilst climate activism has been considered as a subset of the broader environmental movement that evolved in the 1960s and 1970s (O'Brien et al. 2018), it has also been regarded as a new social movement that traverses not only social and political relations but also spatial scales from the local to the global (Barr \& Pollard 2017; North 2011). As such, climate activism has broader transformational aims extending beyond the physical environment; notably, where cities are concerned, the movement aims to connect up the politics of space, scale and circulation to bring about meaningful global societal and environmental changes (Ward et al. 2018). Insofar as local activism relates to the promise of transformational societal change at the global scale (O'Brien \& Leichenko 2019), climate activism has a significant - if not indispensable - global governance role alongside state-led international climate policy institutions and processes, like the United Nations Framework Convention on Climate Change (UNFCCC) Conference of the Parties (COP), as the COP26 quotes above suggest.

Nonetheless, there remains something of a theoretical and practical disconnect between urban and local scale climate activism and formal international climate policymaking. This has prompted North (2011) to differentiate between 'prefigurative' or grassroots action, which is undertaken at the community/local scale, and 'outward' activism, which involves international NGOs and environmental groups lobbying governments at national and international scales. Contemporary climate activism as a civil movement originating in cities, therefore, should not be understated. It has a diffusive quality that attracts a diversity of social actors (e.g. see Hadden 2014) 
into a broader international movement that has mobilised citizens and groups to oppose what they see as inadequate state policy action on climate change through the UN and COP process, despite increased warnings from scientific experts who, ironically, are actually also part of the UN machinery on climate change (IPCC 2018). However, there are many examples of where urban scale civil activism has been marginalised (or even jettisoned) from international climate policy processes like the $\mathrm{COP}$ process because activists feel that the policies transpiring from such negotiations have been inadequate in controlling carbon emissions and enhancing resilience to climate change (de Moor 2018). This has led to activist calls of UN negotiations not being inclusive of citizens. Hence, formal climate policy processes have been criticised as anti-democratic, excluding particular forms of civil protest, whilst maintaining the political status quo of hegemonic state territorialism and capitalism (Chatterton et al. 2013; Craggs \& Mahony 2014; Kythreotis 2012b; Weisser \& Müller-Mahn 2017). A reliance on formal climate policy processes alone has proved wholly inadequate in alleviating the sufferings of many citizens who experience extreme climate impacts as political alliances between member states in the paradoxical international climate governance regime 'game' continue under the failing and arguably inconsistent UN Paris Agreement (Geden 2016; Kythreotis 2015). The agreement is underpinned by a pledge and review system that has been deemed inequitable and dysfunctional in catalysing effective international climate governance action, given the dominant capital-centric realpolitik of the international political economy (Buhr et al. 2014; Ciplet \& Roberts 2017; Falkner 2016; Kemp 2017). This article feeds into this premise.

The juxtapositioning of climate action failure and extreme weather has not gone unnoticed by other powerful international organisations. Climate action failure and extreme weather have been deemed the most significant global threats in terms of both likelihood and impact by the World Economic Forum (World Economic Forum 2020). This further demonstrates why civil action has recently burgeoned as a reaction to the political economy of capitalism, with mass rallies that involve citizens of varied socio-demographics and attitudes (Boucher et al. 2021) e.g. The People's Climate March in 2014, the recent emergence of Extinction Rebellion (XR), (This Is) Zero Hour and the School Strikes Movement (Skolstrejk för Klimatet) garnering momentum on a world stage. Such intra- and inter-generational inspired civil action has made national governments around the world sit up and take a bit more notice of this increasingly diverse populist climate movement, with the understanding that citizens, regardless of age, creed or class, are becoming increasingly frustrated with the lack of climate policy urgency by national governments and the supporting international climate regime under the UN. Arguably, the sheer scale of global civil climate activism has led some governments to declare a climate emergency. Both UK national and 
local governments have declared such emergencies, in some cases as a result of climate activism (Howarth et al. 2021), highlighting the powerful nature of collective, populist climate activism - yet with diverse civil actors - as an important climate policy driver (Piggot 2018).

Given the rapid expansion of the global civil climate movement and resultant declarations of climate emergencies by national and local governments across the UK, this article examines two fundamental questions in relation to contemporary climate activism in the build up to the COP26 climate negotiations in Glasgow, UK in 2021. Firstly, where has climate activism featured in the evolution and declaration of climate emergencies in the UK at large? Secondly, how effective is the civil climate activism movement at the urban scale in holding UK city councils to account for their climate actions? These questions are key in helping us understand how to develop a greater collaboration between civil society and state policymaking through future COP processes. It has been argued that there is a need to establish a relational link between local and urban climate action and global climate governance processes (Kythreotis et al. 2020b). This article uses data from interviews with a range of UK stakeholders involved in climate action in the UK through the form of declarations of local climate emergency, research into urban (city) climate action, or implementation and assessment of democratic deliberative processes on climate change such as citizen juries and assemblies. In so doing we provide a broad representation of the perspectives and interpretations of key state and non-state actors involved in the climate action sphere, as COP26 looms. This involves a close appreciation and critical perspective of the internal and external factors that influence the climate activism-action interface and the role of the state in either facilitating or circumscribing greater statecivil collaboration in climate governance and policy.

After this introduction, the literature review (section 2) contextualises the relationship between new geographical forms of climate activism and the climate emergency with an emphasis on the relationship between climate activism and the state in the context of the climate emergency. Section 3 discusses the methods, followed by a main analytical section (4) that critically discusses the interview findings in relation to our literature review and key questions. Our interview findings pinpoint four distinct themes related to our two research questions concerning the changing geographies of contemporary climate activism and the state as COP26 looms: i) Increased knowledge and awareness - this relates to how knowledge and awareness has grown from an enhanced understanding of scientific knowledge beyond IPCC framings; ii) Strikes and protests as drivers - this relates to how climate activism has acted as a platform for bringing citizen's voices and concerns forward; iii) Building pressure for action this relates to how climate activism helps to provide a social mandate for policymakers to take action to address the climate crisis; and iv) Build-up of multiple elements and 
leverage for action - this relates to how urban climate activism has brought to the fore a critical contingent of mass civil action movements such as Youth Strikes and Extinction Rebellion, and how the rise of these mass movements have provided potential leverage for greater action and a platform for accountability (Martiskainen et al. 2020). Such movements, we argue, have been so impactful because they have occurred during a time when momentum existed, and uptake was more likely. We conclude by briefly discussing the ways in which new forms of climate activism are contributing to the contemporary politics and geographies of climate change and the state-civil relationship by levering a political impasse through the climate emergency. Additionally, we also argue how this year's COP (26) hosted by the UK and Italy needs to recognise that, unlike previous years, understanding civil climate activism, particularly its human and moral dimensions, as part of a governance system that legitimately involves scientists, the state, activists and citizens, is central in catalysing a more democratic and inclusively defined global climate governance under the Paris Agreement that move beyond state-led technocratic climate policy discourse responses.

\section{Literature review}

\subsection{New forms of urban climate activism and the climate emergency}

Climate change has become a focus for a variety of civil urban activism springing up around the world. Although directed globally at thinking through the spaces of circulation in which cities are situated, nonetheless such movements are often place specific and effectiveness varies from city to city. Whilst such movements have distinct modes of knowledge, emotions, motivations and actions (Martiskainen et al. 2020), they are all united through a broader global civil climate movement that is pushing national governments for increased policy action on climate change. The most prominent of these new movements include Extinction Rebellion (often called XR) and the Youth Strike for Climate movement.

Extinction Rebellion is a non-violent direct-action group that was formed in the UK in late 2018. Since then, the movement has spread rapidly with branches around the world. XR's goal is the prevention of further climate change and species diversity loss, through three key demands: (1) Tell the Truth: Government must tell the truth by declaring a climate and ecological emergency, working with other institutions to communicate the urgency for change; (2) Act Now: Government must act now to halt biodiversity loss and reduce greenhouse gas emissions to net zero by 2025; and (3) Beyond Politics: Government must create and be led by the decisions of a Citizens' Assembly on climate and ecological justice (Extinction Rebellion 2020). 
The Youth Strike for Climate is best described as a movement rather than a group. Also known as Fridays for Future, Youth for Climate, and the School Strike for Climate (Skolstrejk för Klimatet), the movement was kick-started by climate activist Greta Thunberg when she staged a solo protest outside the Swedish parliament in August 2018 (Fridays for Future 2020). Since then, it has spread rapidly, with schoolchildren around the world striking on Fridays. Some students take part every week, but most participate less frequently; every few months there is a global strike which attracts much larger numbers. This movement has also led to other youth climate movements springing up, like the Sunrise Movement, Zero Hour and One Up Action.

Extinction Rebellion and the Youth Strike for Climate are the latest iterations of the environmental movement, which first emerged in the 1960s. Some of the pioneering groups of this movement, such as Greenpeace and Friends of the Earth, have grown and become institutionalised over the last few decades, which has enabled them to develop relationships with policymakers in government as trusted consultants (Kythreotis 2012a). However, this has also made them more averse to risk for fear of losing their privileged position (Rootes 1999). New groups such as Extinction Rebellion and Youth Strike for Climate have no such formal relationship with governments. On the one hand, the influence of such groups seems less direct because they are not engaging in the formal policy spaces of government. On the other hand, they are not constrained by the risk of losing access to formal policy spaces and are therefore able to engage in more radical tactics. These autonomous tactics enable such groups to exert direct geographical action across different world cities. In turn, such geographical civil proliferation puts pressure on governments for increased policy action on climate change. This certainly has repercussions in the way that policymakers and decision-makers must be seen to enhance climate ambition at global governance platforms like the COP. The pervasiveness of this new broader climate activist movement also needs to be reflected in the actions of national government decision-makers at global platforms like the COP, because citizens hold sway in holding governments to account for their actions. Thus, it is no coincidence that the declarations of climate emergencies currently witnessed have their provenance in the recent upwelling of contemporary climate activism of groups like XR and the Youth Strikes.

There has been an abundance of literature describing the constitution of climate activism - especially urban climate activism - as a broader social, as well as environmental justice movement (Jamison 2010; McAdam 2017; North 2011; Pettit 2004). Notwithstanding these important social justice elements, the recent climate emergency declarations have cast the role of climate activism in a more influential light on contemporary world climate politics and policy, where new civil social movements led by XR and Greta Thunberg have repositioned a diverse set of civil actors more closely with the necessary formal state policy systems that can catalyse political change 
(Bomberg 2012). In this sense, civil mobilisation over climate change has undergone a sea change in the last few years in terms of being able to garner formal political attention from government institutions and potentially influence wider state climate policy processes.

Featherstone (2013) has argued that the broader climate movement - particularly the way it has highlighted the systemic weaknesses of global neoliberalism - has opened up new ways to think about climate activism beyond 'post-politics' (e.g. a globally defined technocratic and administration management state consensus) that may have different recourses to formal state policy administration and action on climate change. However, others have pointed out how the myriad of new voices coalescing around climate activism does not necessarily mean that government climate policy will result in more equitable change. For example, Kenis (2019), through a study of grassroots climate movements through the lens of the post-political, argued how having different climate movements does not necessarily mean they're an agreed form of climate activist politics. Instead, there are different forms of civil contestation - sometimes in opposition to one another - even though they all draw from post-political understandings of how state climate policy depoliticises certain civil actors. This illustrates the significance of being able to critically intellectualise and understand this new evolving citizen-state relationship in contemporary climate politics and policy. This 'new civil politics of climate change' needs to moves beyond a simple definitional reinterpretation of a dialectical relationship between citizen and state whereby consensus-making over climate politics is dominated by governments and the state, as post-political arguments uphold. Rather there is a need to acknowledge how civil climate activism is entrenched in a more pluralised, nuanced and often place-based climate politics that can significantly influence the way that state policymakers formalise climate policy through this new 'emergency' policy discourse.

Political access of local civil groups to state policy processes and/or institutions will inevitably be differentiated, with the state often choosing which civil actors can suit their own preferred policy management trajectory (Kythreotis 2010; Weisser \& Müller-Mahn 2017). This inevitably depoliticises the very essence of climate activism as an alternative democratic entity that seeks to penetrate elite policymaking spaces that have been historically difficult for civil actors to influence. It also reframes any cogent analysis of climate activism in terms of what 'activism' politically means in the context of the current climate emergency and what equitable role civil society groups can play in contributing to or influencing future climate policy. Indeed, there are arguably many climate emergencies espoused by different civil groups, and the state alike, even though the upshot is that the contemporary broad climate activism we are witnessing has a more active voice than in preceding years. Therefore in this article one of the key questions we ask is where has climate activism featured in the evolution 
and declaration of climate emergencies at the national scale in the UK over the past few years? This key question must be freighted with caveats because we not only have different activist movements e.g. XR, Transitions, Skolstrejk för Klimatet, that make up the broader climate activism social movement (Gunningham 2019; Jamison 2010), but also different ideas - from both activists and state policymakers - as to what constitutes 'climate emergency'. Rootes (2012) has argued how in the UK, bottom-up grassroots initiatives have sometimes moved away from larger Environmental NonGovernmental Organisations (ENGOs) who work more closely with governments in a top-down fashion within the formal confines of the political economy of states. Hence, teasing out the relationship between climate activism and state climate policy action in the context of these recent climate emergency declarations warrants significant empirical examination. This is especially the case in terms of what it means more broadly for how locally-inspired action geographically fits with future global governance of climate change through formal processes like the COP, that are often far removed from the everyday experiences of citizens and their perceptions of what effective climate action constitutes.

\subsection{Climate activism as a precursor for state climate policy action}

A new broader and inclusive form of contemporary climate activism appears to be taking a more prominent role in holding governments to account when it comes to informal civil climate action on the streets, but policy change has been limited despite governments recognising the climate emergency (Gills \& Morgan 2020). Similarly, it has been noted that although many climate protagonists firmly believe greater communication and collaboration is needed between state and non-state actors, there remains some serious systemic (institutional) and collective (governance) barriers to communication and collaboration (Wamsler et al. 2020). So, is there anything different about this new contemporary form of climate activism that has resulted in national and local/city governments declaring climate emergencies? The recent upwelling of UK subnational activism certainly highlights how new civil forms of climate governance could contribute to more rapid and equitable state policy responses to climate change at national and international scales (Galarraga et al. 2017). Recent research by Corry \& Reiner (2020) found that radical climate activism outside of formal policy arenas was correlated with - rather than opposed to - knowledge and interest in policy agendas. This suggests that contemporary climate activism shouldn't be viewed solely as a social civil movement that is traditionally at odds with the state, but rather a more sophisticated and hybrid morphological form that can enable government policy change, without losing its autonomy, diversity or moral messaging (Delina \& Diesendorf 2016). 
Using Erik Olin Wright's theories of social transformation, Stuart et al. (2020) have also recently argued how this broader contemporary climate social movement inspired by XR, Fridays for Future, and the Sunrise Movement has exposed and politicised gaps in the system of reproduction (e.g. our fossil fuel infrastructure) that has enabled meaningful social transformation to become more possible through social emancipation. That is, social emancipation occurs through one or more of three strategies. These are:

(1) interstitial, which bypass the state and create cracks in the current system; the XR and the Skolstrejk för Klimatet movements have certainly done this by proffering alternatives to the current Patriarchal and capital-based political system;

(2) ruptural, which directly confront the current system through confrontation; again there are elements of Skolstrejk för Klimatet and certainly XR that resonate with rupturing - for example, through direct interventions on public infrastructure we have recently seen in cities, that are sympathetic to this strategy, but these tend not to result in effective democratic outcomes; and

(3) symbiotic, which relies on collaboration with the current political system to reform policy of which the pressure from these broad contemporary forms of climate activism have certainly created transformational conditions for citizens and the state to work more closely together in tackling climate change. This last strategy is certainly the ideal strategy for governments - and one that we proffer in this article - as they seek to tackle climate change through formal global processes related to the UNFCCC. Yet the first two strategies are more appealing to climate activists who have (quite rightly) been incalcitrant to the way national governments and global climate platforms have made limited progress on curbing emissions and creating more inclusive participatory climate governance processes over the past 30 years.

Hence, cities (or the 'urban') have inevitably played a key role in climate activism and the climate emergency. Although there is significant variety in the responsibilities and structures of local and city governments globally, adaptation to climate change predominantly occurs at the local/urban scale (Baard et al. 2012; Kythreotis et al. 2020a; McGuirk et al. 2014). By the end of November 2019, more than 1200 city governments and local authorities around the world have passed resolutions declaring a climate emergency, moving away from the 'business as usual' response to climate change taken previously (Davidson et al. 2020). The framing of the situation as an 'emergency' is significant as it implies the need for radical and rapid action, instilling a sense of urgency that has previously been lacking (Davidson et al. 2020). The resolutions that we have witnessed typically contain language recognising that climate change is already having significant irreversible impacts, and a commitment of 
resources to prevent further change and tackle the unavoidable impacts. In the UK, there is a propensity for rural local authorities - especially those controlled by a Conservative Council - to be reluctant in either declaring a climate emergency or at least highlight the fact that declaring such emergencies are not legally binding with national carbon targets. This is a key political tension between rural and city councils in the UK. Cities have become more forthcoming as geographical focal points in catalysing local climate mitigation and adaptation action (Grafakos et al. 2020), although there are also marked differences between urban areas in the UK in terms of climate action and targets (Heidrich et al. 2013). Hence, there remains significant place-based obstacles that hinder the progress of climate action and policy solely through cities. These include the challenge of overcoming UK-wide administrative and political boundaries that exist across local government administrations in twotier areas which makes it difficult for territorially adjacent, overlapping, or political diverse local governments to work together to resolve often contradictory urban and rural considerations and achieve alignment in local climate policy objectives.

As the above implies, declaring a climate emergency is not a guarantee that effective and meaningful action will be taken. In order for attempts to mitigate climate change to be successful, they have to take priority over all other goals and policies, whilst also ensuring that vulnerable groups are not disadvantaged further; even relatively progressive local authorities are unlikely to adopt this approach (Davidson et al. 2020). It is also important to remember that there are limits to the powers of local governments. Without support from both national governments and local communities there is only so much that can be achieved (Davidson et al. 2020), although local councils in the UK do have it in their power to aim for carbon neutrality by 2030 , even though the UK central government target is 2050 (which many rural councils still work to). So, there is an obstacle as to the extent to which local scale government administrations can exert climate policy influence vis-à-vis the political legitimacy/ authority of national scale government (UK). The 2030-2050 target tension is an example of a scalar political tension that is also exacerbated through the UK devolved government system (England, Scotland, Wales, Northern Ireland), which impedes a spatially equitable climate policy consensus between place and scale, resulting in inconsistent climate policy leadership across the UK that can enervate a concerted and consistent UK policy response to climate change at the international scale through the UNFCCC and COP process. In this sense, the local and urban climate policy experience is causally linked to global climate governance processes of the UNFCCC and the COP.

Other obstacles can be the lack of a shared understanding of the meaning and purpose of climate change adaptation (Fünfgeld \& McEvoy 2014). In addition, climate change mitigation and adaptation involves complex and uncertain 
decision-making, which local authorities are often not well-equipped to undertake (Baard et al. 2012). Hence, we see how many cities around the world have been fertile grounds for inspiring climate policy leadership (e.g. see Homsy 2018; Wurzel et al. 2019), whilst rural areas can lag behind (e.g. see Fallon \& Sullivan 2014). This urban-rural dichotomy creates inconsistent climate change action across distinct state territorial jurisdictions, which in turn, has necessitated the upwelling of new forms of climate action through different social movements springing up across society. What follows is an empirical analysis of how the declaration of climate emergencies by local councils in the UK have been influenced by climate activism. We argue that this plays an important role in changing the geographies of climate change governance and policy between the local, national and international scales, where often local action is disconnected from national and international climate forums (Di Gregorio et al. 2019; Kates \& Wilbanks 2003; Kythreotis et al. 2020b)

\section{Methods}

The empirical data and theory presented in this article stems from a UK study undertaken by the ESRC Place-based Climate Action Network (PCAN) and a British Academy grant respectively exploring the extent to which climate emergency declarations are effective ways to enhance (local) climate action and how this 'new civil politics of climate change' is reconfiguring UK state-civil geographies in the context of climate change communication, action and policy. Sixteen semi-structured interviews were carried out: five (5) UK academics, six (6) policymakers or representatives of policymakers/policy organisations, and five (5) civil society organisations. Interviewees were selected based on their knowledge and experience of climate emergency declarations in the UK, with expertise on climate governance, climate deliberation, climate activism, climate policy and decision-making. Interviewees were asked a series of questions on UK climate emergency declarations and in this article we focus on the broader question around the evolution of the climate emergency declarations (from their inception to the declaration being made) and the role that civil activism did or did not play in this process as a means to form new insights into the changing geographies and relationship between contemporary civil activism and government policy action on climate change. These changing geographies would inevitably have upscale implications to the way global climate governance processes at the COP are undertaken. Interviews took place in the UK in person or over the phone, lasting up to one hour each, and audio transcripts were transcribed and analysed using thematic analysis. 


\section{Findings}

The findings of this research are based around two major questions. Firstly, where has climate activism featured in the evolution and declaration of climate emergencies at the urban and national scales? Secondly, how effective is climate activism and civil society movements in holding councils to account for their climate actions? A number of prevalent themes related to these two questions emerged from the interview analysis that would be directly relevant to COP26's policy trajectory of a more inclusive and collaborative relationship between state and civil actors in future negotiations.

\subsection{Increased knowledge and awareness}

The first main issue that emerged out of the interviews suggested that increased knowledge and awareness of the climate crisis has grown from the enhanced scientific knowledge (e.g. IPCC $1.5^{\circ} \mathrm{C}$ report published in 2018) on the risks the world faces and the need for a $1.5^{\circ} \mathrm{C}$ target. Resulting activism builds on this and is reflected in climate strikes and the XR movement which acted to bring together citizens and increase public salience of the types of risks they may be exposed to. Several interviewees touched on this in interviews:

I think what we saw was amazing coming together by this time last year, of a public awareness of the IPPC stuff, which was interesting because normally there's not that much public awareness right, it's kind of like quite [techy]. Interviewee 6

But that really got out didn't it that, in November 2018 before. And then by Spring 2019, we had a big understanding of that 1.5-degree thing, everybody was talking about 1.5 degrees. And then that came together with Extinction Rebellion, who were really live and pushing debate on the street. Interviewee 6

the sudden uptake in an interest in pollution (...) which then leads to a broadening of the debate so that members of the public begin to talk about a public policy issue which precisely feeds into the debate about the environment. Interviewee 8

The above chimes with the findings of Ogunbode et al. (2020), who found that if people were newly exposed to the $1.5^{\circ} \mathrm{C}$ IPCC report their concern and awareness of dangerous climate change were enhanced. This awareness, combined with increasing coverage of climate change, its impacts and solutions, has been further legitimised by demonstrable interest and stepping up of several local authorities through their own climate emergency declarations. As a few interviewees alluded to:

there have been councillors in most of the councils who have picked this up and run with it. But they have been able to get the declarations through because there's clear public support, you know, that most of the council meetings where these have been successful, 
the public galleries have been packed. And it was definitely triggered by the IPCC report, the ten years left report. That's kind of where it all started. And the growing understanding of the urgency. Interviewee 2

I think that the declarations and all the information around the press coverage and social media has helped to put this topic into the agenda of the people in these councils. We know this is one topic that is important for the people and with elections the candidates will try to allure them and include those concerns into their political platforms. Interviewee 3

Other interviewees expressed the view that the current activity (and that since 2018) witnessed in the UK has built on an underlying interest and historical public knowledge of the risk of climate change, from particularly younger generations. Hence by not starting 'from scratch' this renewed awareness has come at a time where society has demonstrated a stronger interest and response mirroring, and mirrored by, responses by individuals in positions of power.

I think we've come back to a place where some real hard-hitting facts have been given to us. And councils, as leaders of their local place, are building on their role that they've been playing to sort of put this more at the forefront of a local place's agenda. And I think at that point people maybe thought that we needed to do something about this, which is maybe a bit more drastic. Interviewee 12

And climate change was much higher up the political agenda in young people's viewpoints than perhaps the older generation. Interviewee 10

Climate change was coming back up the agenda anyway, kind of before [Greta], who I think is a key influence and also I think Extinction Rebellion. So, I think to an extent they weren't building from a zero platform. Interviewee 10

So, in terms of awareness raising amongst the general public, the recent $1.5^{\circ} \mathrm{C}$ IPCC report was helpful, but there also were also pre-existing policy conditions that had been created through the recent upwelling of social climate movements that made governments sit up and take greater notice. This also resonates with the opportunity streams of Kingdon (1995) who argued that a problem stream was created when an issue like climate change lurches more prominently into public attention. This is then followed by a policy stream where a solution is available to governments. This then creates a politics stream, whereby governments have declared climate emergencies in a collective fashion. The strikes and protests were certainly central to creating the politics stream, as the next subsection illustrates. 


\subsection{Strikes and protests as drivers}

Building on the dissemination and prominence of the evidence base on the risk of climate change and the need to reduce emissions to a $1.5^{\circ} \mathrm{C}$ target, citizen activism played an important role in building a platform from which citizens' voices and concerns became more vocal and governments began to witness that greater policy changes was needed. There was a strong sense in our interviews that grassroot activities, energy and a sense of urgency has provided a space for local forms of democracy to be heard and catalyse the need for greater climate policy action:

And I think the population has, you know, grass roots have come up and said we need to do something about this and change it. And I think local democracy has responded to that. Interviewee 11

I think those small groups of people that have organised Extinction Rebellion and climate strikes have had a profound impact on the dialogue and the space. Interviewee 14

It has definitely been fuelled by extinction rebellion and the youth strikers. Interviewee 2

The school strikes, the Greta Thunberg and related campaigning issues, protest movements like Extinction Rebellion, I think have helped to shift public and political opinion. Interviewee 4

The above interview quotes suggest an enabling of old dialogues being revisited and new ones forming, all driven by a desire to go 'beyond' knowledge exchange and instead put pressure on those who have an important role to play in shaping future climate action. While climate strikes and activist organisations such as XR have played a vital role in shaping the UK national policy conversation on climate action (Gunningham 2019), local pockets of voices exogenous to the state have equally been instrumental in advocating for local governance and action (e.g. see Corry \& Reiner 2020) in order to respond to the climate crisis:

I think decisions by people in positions of authority can be greatly impacted by outside pressure, and I think the combination of having school climate strikes (...) there was a period of six months where fairly regularly there was several thousand people outside the council chambers. And this was happening all around the country. As well as all of the media and the noise the Extinction Rebellion had generated, I think, it had a profound effect on things. Interviewee 14

I think that the way that the emergency declarations were made was very strongly influenced by the external pressures of the social groups. And I think that's in the moment in that context, the councils are quite receptive to these suggestions and probably one political party or one member of the council took the proposal and put it forward. So, there was no way they would run away from it. Interviewee 3 
Of course, smaller groups of individuals, constituents, they put pressure on their council leaders as well. And a few champions within cabinet and local authorities that have taken this forward and basically said 'now we need to do something about this'. Interviewee 5

Hence, we see how local action, whether related to the state or not, has a key policy influence at other higher geographical scales. Schwartz (2019) found that enhanced local climate action, particularly in large urban conurbations created greater intergovernmental relations (with national and international policy scales) with respect to climate policy action enhancement, although there was a requirement for greater national government support in some localities who had less effective climate action spheres. This indicates how local activism remains a key driver for policy change at higher policy scales, in order to build greater pressure for action from below. This has also been reported in analyses of UK local authorities, where though the role of the citizen has been important in councils' declarations of a climate emergency, people will only buy into the declarations if local authorities can show how tackling climate change will improve local well-being (Gudde 2020). Building greater pressure for action is further explored in the next subsection.

\subsection{Building pressure for action}

All climate activism activities played a role in building pressure and build on past momentum of awareness of climate change. In so doing, many interviewees claimed that these activities helped to bring to the fore widespread civil society awareness and dissatisfaction with ongoing political efforts, and a call for greater climate action which undoubtedly led to a tipping point beyond which the climate crisis was seen to be taken more seriously by policymakers, as evidenced in the amount of climate emergency declarations occurring over the past few years. As the following interviewees argued:

I think you know, you have the one point five-degree report, it got a lot of press [and] of course you had the school climate strikes and then the extinction rebellion protest. There has been this up soaring of kind of momentum around climate action for the last what 18 months or so and I think that's where it's kind of getting people to say 'Right, we really need to do something about this' and it's getting some political support. Interviewee 1

You can't discount the idea that maybe they suddenly made it a priority because it's getting a lot more attention. Interviewee 1

The increasing pressure resulting from the growing civil unrest regarding climate change provided an opportunity for policy responses to mirror what activist citizens where calling for through these strikes: 
And I think that the Climate Emergency Declarations were very much a political response to that. Interviewee 11

And so that kind of disruption, from my perspective, has been quite an important force in pushing councils. And then they've kind of - and then there's the peer pressure amongst councils. Interviewee 13

The above quotes show the power of broader social movement pressure in facilitating policy change regardless of the ideological creed of the government administration in question. In the UK, there is an established tradition of greater climate action being supported by the Labour Party, where the Conservatives have traditionally been less pro-environmental (Carter 2014; Carter \& Jacobs 2014; Carter et al. 2018). Whilst more recently in the UK, this division has been less pronounced, particularly at the local authority level, many rural councils controlled by Conservative councils (e.g. Lincoln County Council) are being less ambitious with their future climate plans and have aligned local climate planning policy with the national government 2050 net zero carbon target, whilst Labour controlled local authorities (e.g. Lincoln City Council) have targeted being net zero carbon emissions by 2030 in their local planning, which has partly been driven by new local climate governance institutions like local Climate Commissions that have local authority support and private, community and third sector buy-in which ramps up bottom-up activism beyond the state.

\subsection{Build-up of multiple elements and leverage for action}

Climate activism appears to have conjoined hitherto disconnected phenomena relating to climate change and critical mass, namely, the IPCC $1.5^{\circ} \mathrm{C}$ report, the Youth Strikes and XR. This build-up of momentum contributed to a combination of growing pressure to act, as well as to be seen to be responding with appropriate agency to the climate crisis. It has been pointed out by Castree (2020), that moving beyond the abundant (albeit arguably monistic) broad physical evidence we see in global environmental assessments that proposition a climate emergency because of the surpassing of a number of physical and biological planetary boundaries, to a plan of direct state action, remains somewhat elusive. Whilst action is still needed on the part of governments (as the interview quotes in section 4.3 alluded to), such action needs to involve various types of (citizen) social agency (e.g. XR, School Strikes, Sunrise) that moves society beyond the institutionalised science (which has identified the problem) and government (with its piecemeal and inadequate tackling of the climate crisis through the UN) response to tackle climate crises (Castree et al. 2020; Kythreotis et al. 2019). 
Increased action(s) through the broad types of contemporary climate activism we are witnessing have been integral in pushing the climate crisis up the political agenda:

So, there's kind of a confluence of different events that were shoving climate change up the agenda, which meant, you know, the presses actions then were, you know, more a spark to a kind of dry kindling. Interviewee 10

So, in 2018 towards the end of the year, you had Extinction Rebellion, the school strikes. I can't remember when the school strikes started but, you know, Greta Thunberg and the IPCC report and I think all these kind of came together at a similar time and said, you know, 'There's a big problem going on there.' So, yeah, I think it was the coalescing of all those things at once. Interviewee 15

I think this absolute momentum, monumental momentum, where people realise that, there's a bit, I think a lot of it was peer pressure, and a lot of it was not understanding what they were signing up to. Interviewee 6

I know that there was this huge upsurge through both in the Climate Strikes and then Extinction Rebellion from the citizens really wanting more action. Interviewee 11

These activities play an instrumental role in helping to both pressure and persuade those in authority not only of the need to act but also that there is a social mandate to do so. Interviewees then suggest that this increased pressure and momentum to some extent, gives policy actors 'permission' to build on this mandate, enabling a snowball effect to occur whereby one after another local authorities began to declare their own local climate emergencies:

I think that civil society has a really important role in persuading institutions, and clearly my own, I guess, but not mainly my own because we are by nature an environmental organisation. But in persuading the authorities, democratic and otherwise that they need to change and public policy needs to change and that organisational and individual behaviour needs to change and I think without that civil society pressure, you wouldn't get that democratic response, I don't think. Interviewee 4

And then found the political allies that happened to create these coalitions. From there on I think it was more like a snowball. There was the BBC documentary on climate change with David Attenborough, then the COP two years ago. Interviewee 3

A number of interviewees $(5,7,10)$ also speculated that one of the reasons why the climate strikes and XR movement had been so impactful was that they took place at a specific time, where momentum already existed and were building on fertile ground. 
I think the way we have politicised through Brexit and other things, possibly also helped. People became over the last five years much more active, took to the streets, many different agendas. And I think that level of activism nurtures also the green movement. Interviewee 7

Probably brewing under the surface for a while and it's emerged in this way. Interviewee 5

And XR's actions also landed on very fertile ground. I think that's, you know, and the Green Party were, you know, they had [canvassed] and canvassed across the country, you know, not huge amounts but a good sprinkling in places as well. And particularly that enabled them to think about what we need as local authority motions in this space. Interviewee 10

In so doing, they provide a loud moral voice to wider civil society on climate change providing leverage for action and a platform for accountability.

I think that confluence of actions and particularly a kind of the Greta effect and the young people standing up I think had a massive moral voice behind it. XR I think was more polarising (...). Interviewee 10

The ongoing citizen's engagement and the constituent engagement process. If one of the reasons is pressure from constituents that have made them declare this and they would expect a follow-up - action plans, things like that. The constituents, not all of them of course, but the noisy ones will continue to make noise and the momentum gained by declaring an emergency can only last so long. But what comes after and how do they intend to engage with their constituents and say 'yes, we've declared it - yes, we met your goal: now don't speak to us for another ten years.' Obviously, that's not going to happen. They will come back in a few months' time and say 'well, where's the plan? What have you done? How are you investing it? What are you going to do?' I think that's - how are they going to navigate that politics, because it would be interesting, I think. It would be interesting to ask, in fact, how they're doing that. Interviewee 5

The role that grassroots organisations and civil actors play in this regard is one of accountability in that they have both provided the social mandate for policy action on climate change, and the delivery of local climate action plans, whilst simultaneously providing a mechanism for holding these actors to account. This further degree of accountability (or perceived at least) not only legitimises the role of civil activism in climate action design and implementation but ensures that this action is robust and adheres to demands and requests from non-state actors. In so doing it provides a more effective way to monitor, evaluate and alter processes as and when they evolve. 


\section{Conclusion}

This article has sought to examine and re-evaluate the changing geographies of climate activism and the state in the post-climate emergency era in the build-up to COP26. Through interviews with key stakeholders we have found that there was a perception amongst our interviewees that climate activism has played a much more prominent role in influencing decision-making processes at the national scale, particularly in pre-empting government climate emergency declarations. The interviews also revealed the importance of urban climate action to the broader global climate social movement, particularly the activities of XR and School Strikes, which have provided a human-centred foregrounding to the shortcomings of previous national government climate policymaking - a 'national scalar policy dissonance' - which has relied on ill-defined arbitrary temperature targets and other technofixes in tackling dangerous climate change. Additionally, the recent mobilisation and success of new (urban) forms of climate activism in catalysing a new climate emergency discourse is significant in as much as it highlights a civil society reaction to the major weakness in the way national states have politically ratified a Paris Agreement in international negotiations of the COP. This system is built upon a 'house of cards' pledge and review system that can easily be reneged upon within the existing institutional governance structures of the UNFCCC - an 'international collective scalar policy dissonance' that signposts a significant weakness of the institutional and governance structures of international climate governance forums. The increase in recent strikes and protests - the new civil politics of climate change - have helped raise public and state awareness of the acuteness of the climate emergency and have started to build greater pressure for action within nations, including the UK. However, real policy change has yet to be fully realised through the decision-making processes of the COP and UNFCCC.

There also remain challenges of upscaling from the local/urban action to the national and international scales as our interviews revealed. There is a need to build more effective political alliances across cities and rural areas in order to meet national, and therefore, global climate targets through the Paris Agreement. For that, local climate activism in its broadest sense, needs the recognition and support of local government. Whilst specific movements like XR have been more extreme in how they have gone about demanding this through action (and disruption) that goes 'beyond politics', their tactics have certainly made national governments sit up and take notice, which our findings found were essential in catalysing the climate emergency discourse. The School Strikes movement can also be construed as being just as extreme as the XR movement because it involved disruption of a system of education predicated upon meritocratic principles which are sympathetic to global capital accumulation. This highlights a disconnect between local activism and international policy action. 
Local activism seeks to highlight the uneven distribution of climate impacts between those disenfranchised by abrupt climate impacts and those social and political elites who do not experience dangerous climate change impacts, but have been tasked with the political tools to actually tackle climate change by having a seat at the international climate negotiating table through forums like the COP.

This brings us squarely back to how those decision-making elites at COP meetings (forthcoming COP26 at the time of writing) choose how to acknowledge at worst, or include at best, the emerging role of the broader climate activism we have recently witnessed around the world. There is certainly an evolving relationship between climate activism and the UK state, which we have empirically illustrated in this article. No longer can climate activism be viewed as a deterrent or a usurper of formal climate policymaking by political elites. We argue that this changing civil-state relationship is not just solely attributed to the efficacy of climate activism as an oppositional form to the state in toto, but also reflects a societal-wide non-discriminatory intra- and inter-generational reaction to the traditional dominant political economy regime of national governments at COPs. Such an inclusive civil reaction has certainly been necessary to lay the groundwork for fundamental changes on the climate policy implementation side at the international scale. For states to acknowledge that a climate emergency is omnipresent and rooted in the everyday lives of citizens, future policy progress will involve a need to move beyond a policy goal of mitigating the arbitrary temperature target of $<2^{\circ} \mathrm{C}$ using a pledge and review system. Taking a more human-centred approach to policymaking, beyond technocracy, must be explored further in the negotiations at COP26. If COP26 policymakers are to recognise, acknowledge and lay a platform for this, then future COP negotiations will be able to better navigate the geopolitical, economic and territorial tensions between different UNFCCC member states more empathetically, diplomatically and effectively.

Likewise, the broader climate activist movement also needs to acknowledge the limitations of national state policy discourses in being a 'silver bullet' in neutralising the climate emergency and reducing global climate emissions and impacts. The COVID-19 pandemic has certainly illustrated the limitations of national government policymaking in instigating change, even when policy changes have been highly reactive, immediate and extreme, e.g. when R-rates have risen. Yet the 'covid catalyst' has has also shown how both activists and the state need to deliberate together more to create a shared social mandate for more concerted future climate policy action (Howarth et al. 2020). A future shared socio-political imaginary based fundamentally on human and moral dimensions as key drivers for change - the raison d'être of climate activism - and acknowledged and supported by scientific and political institutions, will determine whether future climate policy action is successful or not. This is what the decision-makers at COP26 need to take greater heed of if we are to success- 
fully connect local, national and international scales through a more effective and socially inclusive climate governance.

\section{Acknowledgements}

The authors gratefully acknowledge the support from the British Academy and the Department for Business, Energy and Industrial Strategy for a British Academy grant examining the New Civil Politics of Climate Change in the UK (Ref. SRG19\190291) and the UK Economic and Social Research Council through the Place-Based Climate Action Network (P-CAN) (Ref. ES/S008381/1).

\section{References}

Baard, P., Vredin Johansson, M., Carlsen, H. \& Edvardsson Björnberg, K. (2012), 'Scenarios and sustainability: tools for alleviating the gap between municipal means and responsibilities in adaptation planning', Local Environment, 17(6-7): 641-662. https://doi.org/10.1080/13549839.2011.646969

Barr, S. \& Pollard, J. (2017), 'Geographies of Transition: Narrating environmental activism in an age of climate change and "Peak Oil", Environment and Planning A: Economy and Space, 49(1): 47-64. https://doi.org/10.1177/0308518X16663205

Bomberg, E. (2012), 'Mind the (Mobilization) Gap: Comparing Climate Activism in the United States and European Union', Review of Policy Research, 29(3): 408-430. https://doi.org/10.1111/j.1541-1338.2012.00566.x

Boucher, J., Kwan, G.T., Ottoboni, G.R. \& Mccaffrey, M.S. (2021), 'From the suites to the streets: Examining the range of behaviors and attitudes of international climate activists', Energy Research \& Social Science, 72: 101866. https://doi.org/10.1016/j.erss.2020.101866

Buhr, K., Roth, S. \& Stigson, P. (2014), 'Climate Change Politics through a Global Pledge-and-Review Regime: Positions among Negotiators and Stakeholders', Sustainability, 6(2): 794-811. https://doi.org/10.3390/su6020794

Carter, N. (2014), 'The politics of climate change in the UK', Wiley Interdisciplinary Reviews: Climate Change, 5(3): 423-433. https://doi.org/10.1002/wcc. 274

Carter, N. \& Jacobs, M. (2014), 'Explaining radical policy change: the case of climate change and energy policy under British New Labour Government 2006-10', Public Administration, 92(1): 125-141. https://doi.org/10.1111/padm.12046

Carter, N., Ladrech, R., Little, C. \& Tsagkroni, V. (2018), 'Political parties and climate policy', Party Politics, 24(6): 731-742. https://doi.org/10.1177/1354068817697630

Castree, N. (2020), 'The environmental humanities in "the age of consequences", Ecocene: A Journal of the Environmental Humanities, 1(1): 32-43. https://doi.org/10.46863/ecocene.2020.4

Castree, N., Bellamy, R. \& Osaka, S. (2020), 'The future of global environmental assessments: Making a case for fundamental change', The Anthropocene Review, 205301962097166. https://doi.org/10.1177/2053019620971664

Chatterton, P., Featherstone, D. \& Routledge, P. (2013), 'Articulating Climate Justice in Copenhagen: Antagonism, the Commons, and Solidarity', Antipode, 45(3): 602-620. https://doi.org/10.1111/J.1467-8330.2012.01025.X 
Ciplet, D. \& Roberts, J. T. (2017), 'Climate change and the transition to neoliberal environmental governance', Global Environmental Change, 46: 148-156. https://doi.org/10.1016/j.gloenvcha.2017.09.003

Corry, O. \& Reiner, D. (2020), 'Protests and Policies: How Radical Social Movement Activists Engage with Climate Policy Dilemmas', Sociology, 003803852094310. https://doi.org/10.1177/0038038520943107

Craggs, R. \& Mahony, M. (2014), 'The Geographies of the Conference: Knowledge, Performance and Protest', Geography Compass, 8(6): 414-430. https://doi.org/10.1111/gec3.12137

Davidson, K., Briggs, J., Nolan, E., Bush, J., Håkansson, I. \& Moloney, S. (2020), 'The making of a climate emergency response: Examining the attributes of climate emergency plans', Urban Climate, 33. https://doi.org/10.1016/j.uclim.2020.100666

de Moor, J. (2018), 'The "efficacy dilemma" of transnational climate activism: the case of COP21', Environmental Politics, 27(6): 1079-1100. https://doi.org/10.1080/09644016.2017.1410315

Delina, L.L. \& Diesendorf, M. (2016), 'Strengthening the climate action movement: strategies from contemporary social action campaigns', Interface, 8(1): 117-141.

Di Gregorio, M., Fatorelli, L., Paavola, J., Locatelli, B., Pramova, E., Nurrochmat, D.R., ... Kusumadewi, S. D. (2019), 'Multi-level governance and power in climate change policy networks', Global Environmental Change, 54: 64-77. https://doi.org/10.1016/j.gloenvcha.2018.10.003

Extinction Rebellion (2020), 'Our Demands - Extinction Rebellion UK'. Retrieved 25 November 2020, from https://extinctionrebellion.uk/the-truth/demands/

Falkner, R. (2016), 'The Paris Agreement and the new logic of international climate politics', International Affairs, 92(5): 1107-1125. https://doi.org/10.1111/1468-2346.12708

Fallon, D.S.M. \& Sullivan, C.A. (2014), 'Are We There Yet? NSW local governments' progress on climate change', Australian Geographer, 45(2): 221-238. https://doi.org/10.1080/00049182.2014.899030

Featherstone, D. (2013), 'The Contested Politics of Climate Change and the Crisis of Neo-liberalism', ACME: An International Journal for Critical Geographies, 12(1): 44-64. Retrieved from https://www.acme-journal.org/index.php/acme/article/view/951

Fridays for Future (2020), 'Fridays For Future is an international climate movement active in most countries and our website offers information on who we are and what you can do'. Retrieved 1 December 2020, from https://fridaysforfuture.org/

Fünfgeld, H. \& McEvoy, D. (2014), 'Frame Divergence in Climate Change Adaptation Policy: Insights from Australian Local Government Planning', Environment and Planning C: Government and Policy, 32(4): 603-622. https://doi.org/10.1068/c1234

Galarraga, I., de Murieta, E.S. \& França, J. (2017), 'Climate policy at the sub-national level', in Trends in Climate Change Legislation (Edward Elgar Publishing Ltd), 143-174. https://doi.org/10.4337/9781786435781.00018

Geden, O. (2016), 'The Paris Agreement and the inherent inconsistency of climate policymaking', Wiley Interdisciplinary Reviews: Climate Change, 7(6): 790-797. https://doi.org/10.1002/wcc.427

Gills, B. \& Morgan, J. (2020), 'Global Climate Emergency: after COP24, climate science, urgency, and the threat to humanity', Globalizations, 17(6): 885-902. https://doi.org/10.1080/14747731.2019.1669915

Grafakos, S., Viero, G., Reckien, D., Trigg, K., Viguie, V., Sudmant, A., ... Dawson, R. (2020), 'Integration of mitigation and adaptation in urban climate change action plans in Europe: A systematic assessment', Renewable and Sustainable Energy Reviews, 121: 109623. https://doi.org/10.1016/j.rser.2019.109623

Gudde, P. (2020, August), 'Local authorities and climate action', Transform. Retrieved from https:// transform.iema.net/article/local-authorities-and-climate-action?utm_source=Adestra\&utm_ medium $=$ email\&utm_term $=$ 
Gunningham, N. (2019), 'Averting Climate Catastrophe: Environmental Activism, Extinction Rebellion and coalitions of Influence', King's Law Journal, 30(2): 194-202.

https://doi.org/10.1080/09615768.2019.1645424

Hadden, J. (2014), 'Explaining Variation in Transnational Climate Change Activism: The Role of InterMovement Spillover', Global Environmental Politics, 14(2): 7-25. https://doi.org/10.1162/GLEP_a_00225

Heidrich, O., Dawson, R.J., Reckien, D. \& Walsh, C.L. (2013), 'Assessment of the climate preparedness of 30 urban areas in the UK', Climatic Change, 120(4): 771-784.

https://doi.org/10.1007/s10584-013-0846-9

Homsy, G.C. (2018), 'Unlikely pioneers: creative climate change policymaking in smaller U.S. cities', Journal of Environmental Studies and Sciences, 8(2): 121-131. https://doi.org/10.1007/s13412-018-0483-8

Howarth, C., Bryant, P., Corner, A., Fankhauser, S., Gouldson, A., Whitmarsh, L. \& Willis, R. (2020), 'Building a Social Mandate for Climate Action: Lessons from COVID-19', Environmental and Resource Economics, 76(4): 1107-1115. https://doi.org/10.1007/s10640-020-00446-9

Howarth, C., Lane, M. \& Fankhauser, S. (2021). 'What next for local government climate emergency declarations? The gap between rhetoric and action', Climatic Change 167, 27 https://doi.org/10.1007/s10584-021-03147-4

IPCC (2018), Global Warming of $1.5^{\circ} \mathrm{C}$ : An IPCC special report on the impacts of global warming of $1.5^{\circ} \mathrm{C}$ above pre-industrial levels and related global greenhouse gas emission pathways, in the context of strengthening the global response to the threat of climate change, sustainable development, and efforts to eradicate poverty.

Jamison, A. (2010), 'Climate change knowledge and social movement theory', Wiley Interdisciplinary Reviews: Climate Change, 1(6): 811-823. https://doi.org/10.1002/wcc.88

Kates, R.W. \& Wilbanks, T.J. (2003), 'Making the global local: Responding to climate change concerns from the ground up', Environment, 45(3): 12-23. https://doi.org/10.1080/00139150309604534

Kemp, L. (2017), 'A systems critique of the 2015 Paris agreement on climate', in Pathways to a Sustainable Economy: Bridging the Gap between Paris Climate Change Commitments and Net Zero Emissions (Springer International Publishing), 25-41. https://doi.org/10.1007/978-3-319-67702-6_3

Kenis, A. (2019), 'Post-politics contested: Why multiple voices on climate change do not equal politicisation', Environment and Planning C: Politics and Space, 37(5): 831-848. https://doi.org/10.1177/0263774X18807209

Kingdon, J. (1995), Agendas, alternatives, and public policies, 2nd edn (New York, Longman).

Kythreotis, A.P. (2010), 'Local Strategic Partnerships: A panacea for voluntary interest groups to promote local environmental sustainability? The UK context', Sustainable Development, 18(4): https://doi.org/10.1002/sd.487

Kythreotis, A.P. (2012a), 'Autonomous and pragmatic governance networks: Environmental leadership and strategies of local voluntary and community sector organizations in the United Kingdom -ORCA', in D.R. Gallagher (ed.), Environmental Leadership: A Reference Handbook (Thousand Oaks CA, Sage), 282-94. https://doi.org/10.4135/9781452218601.n31

Kythreotis, A.P. (2012b), 'Progress in global climate change politics? Reasserting national state territoriality in a "post-political" world', Progress in Human Geography, 36(4): 457-474. https://doi.org/10.1177/0309132511427961

Kythreotis, A.P. (2015), 'Carbon pledges: Alliances and ambitions', Nature Climate Change, 5(9). https://doi.org/10.1038/nclimate2764

Kythreotis, A.P., Jonas, A.E.G. \& Howarth, C. (2020a), 'Locating climate adaptation in urban and regional studies', Regional Studies, 54(4): 576-588.

https://doi.org/10.1080/00343404.2019.1678744 
Kythreotis, A.P., Jonas, A.E.G., Mercer, T.G. \& Marsden, T.K. (2020b), 'Rethinking urban adaptation as a scalar geopolitics of climate governance: climate policy in the devolved territories of the UK', Territory, Politics, Governance. https://doi.org/10.1080/21622671.2020.1837220

Kythreotis, A.P., Mantyka-Pringle, C., Mercer, T.G., Whitmarsh, L.E., Corner, A., Paavola, J., ... Castree, N. (2019), 'Citizen social science for more integrative and effective climate action: A sciencepolicy perspective', Frontiers in Environmental Science, 7(FEB).

https://doi.org/10.3389/fenvs.2019.00010

Martiskainen, M., Axon, S., Sovacool, B.K., Sareen, S., Furszyfer Del Rio, D. \& Axon, K. (2020), 'Contextualizing climate justice activism: Knowledge, emotions, motivations, and actions among climate strikers in six cities', Global Environmental Change, 65. https://doi.org/10.1016/j.gloenvcha.2020.102180

McAdam, D. (2017), 'Social Movement Theory and the Prospects for Climate Change Activism in the United States', Annual Review of Political Science, 20(1): 189-208. https://doi.org/10.1146/annurev-polisci-052615-025801

McGuirk, P., Dowling, R. \& Bulkeley, H. (2014), 'Repositioning urban governments? Energy efficiency and Australia's changing climate and energy governance regimes', Urban Studies, 51(13): 27172734. https://doi.org/10.1177/0042098014533732

North, P. (2011), 'The Politics of Climate Activism in the UK: A Social Movement Analysis. Environment and Planning A: Economy and Space, 43(7): 1581-1598. https://doi.org/10.1068/a43534

O'Brien, K. \& Leichenko, R. (2019), 'Toward an integrative discourse on climate change', Dialogues in Human Geography, 9(1): 33-37. https://doi.org/10.1177/2043820619829933

O’Brien, K., Selboe, E. \& Hayward, B.M. (2018), 'Exploring youth activism on climate change: Dutiful, disruptive, and dangerous dissent', Ecology and Society, 23(3): https://doi.org/10.5751/ES-10287-230342

Ogunbode, C.A., Doran, R. \& Böhm, G. (2020), 'Exposure to the IPCC special report on $1.5^{\circ} \mathrm{C}$ global warming is linked to perceived threat and increased concern about climate change', Climatic Change, 158(3-4): 361-375. https://doi.org/10.1007/s10584-019-02609-0

Pettit, J. (2004), 'Climate Justice: A New Social Movement for Atmospheric Rights', IDS Bulletin, 35(3): 102-106. https://doi.org/10.1111/j.1759-5436.2004.tb00142.x

Piggot, G. (2018), 'The influence of social movements on policies that constrain fossil fuel supply', Climate Policy, 18(7): 942-954. https://doi.org/10.1080/14693062.2017.1394255

Rootes, C.A. (1999), 'The transformation of environmental activism: Activists, organizations and policy-making', Innovation, 12(2): 155-173. https://doi.org/10.1080/13511610.1999.9968595

Rootes, C.A. (2012), 'Climate change, environmental activism and community action in Britain', Social Alternatives, 31(1): 24-28. Retrieved from https://search.informit.com.au/documentSummary;dn=201206398;res=IELAPA;type=pdf

Schwartz, E. (2019), 'Autonomous Local Climate Change Policy: An Analysis of the Effect of Intergovernmental Relations Among Subnational Governments', Review of Policy Research, 36(1): 50-74. https://doi.org/10.1111/ropr.12320

Stuart, D., Gunderson, R. \& Petersen, B. (2020), 'The climate crisis as a catalyst for emancipatory transformation: An examination of the possible', International Sociology, 35(4): 433-456. https://doi.org/10.1177/0268580920915067

UK Government \& United Nations (2020), 'HOME - UN Climate Change Conference (COP26) at the SEC - Glasgow 2021'. Retrieved 25 November 2020, from https://www.ukcop26.org/

Wamsler, C., Schäpke, N., Fraude, C., Stasiak, D., Bruhn, T., Lawrence, M., ... Mundaca, L. (2020), 'Enabling new mindsets and transformative skills for negotiating and activating climate action: Lessons from UNFCCC conferences of the parties', Environmental Science and Policy, 112, 227235. https://doi.org/10.1016/j.envsci.2020.06.005 
Ward, K., Jonas, A. E. G., Miller, B. \& Wilson, D. (2018), The Routledge Handbook on Spaces of Urban Politics, 1st edn (London, Routledge). https://doi.org/10.4324/9781315712468-1

Weisser, F. \& Müller-Mahn, D. (2017), 'No Place for the Political: Micro-Geographies of the Paris Climate Conference 2015', Antipode, 49(3): 802-820. https://doi.org/10.1111/anti.12290

World Economic Forum (2020), The Global Risks Report. Retrieved from http://www3.weforum.org/docs/WEF_Global_Risk_Report_2020.pdf

Wurzel, R.K.W., Moulton, J.F.G., Osthorst, W., Mederake, L., Deutz, P. \& Jonas, A.E.G. (2019), 'Climate pioneership and leadership in structurally disadvantaged maritime port cities', Environmental Politics, 28(1): 146-166. https://doi.org/10.1080/09644016.2019.1522039

\section{Notes on the authors}

Dr Andrew P. Kythreotis is Senior Lecturer in Political Geography, in the School of Geography, University of Lincoln, a Lincoln Climate Commissioner, and a Senior Researcher at the Tyndall Centre for Climate Change Research, University of East Anglia.

Dr Candice Howarth is Senior Policy Fellow at the Grantham Research Institute on Climate Change and the Environment, London School of Economics and Political Science. She is co-Director of the Place-based Climate Action Network (PCAN).

Dr Theresa G. Mercer is Senior Lecturer in Biogeography \& Planetary Health, at the School of Geography, Lincoln Centre for Water and Planetary Health, Lincoln Centre for Ecological Justice, University of Lincoln.

Dr Hannah Awcock is University Teacher in Human Geography, in the School of Geosciences, University of Edinburgh.

Andrew E.G. Jonas is Professor of Human Geography, in the Department of Geography, Geology and Environment, University of Hull.

To cite the article: Andrew P. Kythreotis, Candice Howarth, Theresa G. Mercer, Hannah Awcock and Andrew E.G. Jonas (2021), '2020-Vision: understanding climate (in)action through the emotional lens of loss', Journal of the British Academy, 9(s5): 69-93.

DOI https://doi.org/10.5871/jba/009s5.069

Journal of the British Academy (ISSN 2052-7217) is published by

The British Academy, 10-11 Carlton House Terrace, London, SW1Y 5AH

www.thebritishacademy.ac.uk 
